\title{
Ahmed el-Müsellem el-Mevsılî (ö. 1150/1737) ve ed-Dürru'n-Nakî fi İlmi’l-Mûsikâ Adlı Eseri
}

FAZLI ASLAN

Dr., BAŞÖĞRETMEN

e-posta: fazli.arslan@hotmail.com

\begin{abstract}
Ahmad al-Musallam al-Mousilî and al-Durr al-Nakî fî Ilm al-Mûsikî. The personality of Ahmad al-Musallam al-Mousilî is unknown. The origin of his al-Durr al-Nakî fì Ilm al-Mûsikî was written by Abd al-Mumin al-Balkhî in Persian language and it was translated into Arabic by al-Mousilî. The original title of al-Balkhî was Bayân al-Maqâmat al-Aliyya Maa al-Furûi wa alAwzân al-Asliyya. Al-Mouslî wished to name his translation al-Durr al-Nakî because of his extra significant information. Some of the scholars thought wrongly that al-Balkhî is Safî al-Dîn Abd al-Mumin al-Urmawî thereby this treatise was quoted from works of Safî al-Dîn especially from his al-Risâla al-Sharafiyya. In this study al-Durr al-Nakî was translated into Turkish and indicated this wrong.
\end{abstract}

key words

mûsikî, al-Mousilî, al-Durr al-Nakî, Safî al-Dîn, al-Sharafiyya.

\section{Giriş}

İslam dünyasında mûsikî nazariyatı alanında yazılmış eserlerde, genel olarak iki üslup göze çarpmaktadır. Birincisi, mûsikîde ses sistemi, sesin fiziksel özellikleri, aralıklar ve oranları, makam dizileri ve bunların matematiksel oran değerlerini ele alan, sistemcilerin takip ettiği üslup, ikincisi ise mûsikînin astroloji ile ilişkisini inceleyen, makamların okunacağı vakitlere, insan üzerindeki etkileri gibi konulara değinen eserlerdeki üsluptur. Üzerinde çalıştı̆̆ımız bu risale ikinci grup mûsikî kaynaklarına örnektir. 
Ed-Dürru'n-Nakî̀de, kendi üslubunda yazılan kitaplardan farklı olarak, orijinal ifade ve anlatımlar, önemli bilgiler bulunmaktadır. Eserde makamların dizileri yerine, onların tabiatı, insan ruhu üzerindeki etkilerine değinilir. Müziğin teorisinden daha çok makamların kökenleri ile ilgili olarak mistik tariflere, makamların astroloji ile ilişkisine, değişik vakitlere göre etkilerine yer verilir. Temel makamların her biri bir Peygambere dayandırılır. Özellikle risalenin hacmine göre uzun sayılabilecek giriş bölümünde olduğu gibi, farklı konulara ani geçişler yapılır. Isfahan insanının bidatlerine değinilir. Türklerin sert mizaçlı oldukları için filan makamın iyi geleceği ifade edilir. Risaledeki bu orijinallik, üzerinde çalışma yapma gereği duymamızın ilk sebebidir.

Bizi bu çalışmaya sevk eden diğer husus ise, XIII. yüzyllın ünlü müzik bilimcisi Safiyyüddîn Abdülmümin el-Urmevî’nin er-Risâletü'ş-Şerefiyye'si üzerine doktora çalışması yaparken bu risaleyi okuduğumuzda bunun Şerefiyye'den iktibas edildiği yönündeki iddiaya muttali olmamızdır. Yapılan inceleme neticesinde iki eser arasında hiçbir yakınlığın olmadığını gördük. Bu risaleyi tam metin olarak yayımlayarak hem içerik ve üslup bakımından Safiyyüddîn'in eserleri ile bir ilişkisinin olmadığını ortaya çıkarmak hem de müzik alanında bilimsel çalışma yapanların sınırlı sayıdaki kaynaklarına bir risaleyi daha kazandırmak istedik.

\section{Ahmed el-Müsellem el-Mevsılî, Eserleri ve ed-Dürru'n-Nakî}

Ahmed el-Müsellem el-Mevsılî̀nin biyografisi ile ilgili olarak kaynakların bize verdiği bilgiler, onun ismi, doğum ve ölüm tarihleri ve yazdığı birkaç eserin zikredilmesinden ibarettir. el-Mevsılî’nin tam ismi Ahmed b. Abdurrahman el-Mevsılî el-Kâdiri er-Rufaî'dir. El-Müsellem ${ }^{1}$ olarak bilinir. 1150/ 1737 yılında öldüğü rivayet edilir.2 İsmail Paşa el-Bağdâdî, müellifin üç eser yazdı̆̆ını bildirir: Tezkiretü'l-Mütezekkir ve Tabsıratü'l-Mütebassır, edDürrun'n-Nakî fì Fenni'l-Mûsikâ ve Sirâcü'l-Kelam fi Şerhi'z-Zalâm. ${ }^{3}$ Celal

1 Brockelmann, sin'i sakin okuyarak Müslim olarak yazmıştır. Carl Brockelmann, Geschichte der Arabischen Litteratur, Leiden 1938, Supplementband, II, 508; Shiloah da aynı şekilde okumuş ve al-Muslim olarak yazmıştır. Bkz. Amnon Shiloah, The Theory of Music in Arabic Writings, (c. 900-1900), Munchen, 1979, s. 287.

2 İsmail Paşa el-Bağdadî, Hediyyetu'l-Ârifîn Esmâu'l-Muellifîn Âsâru'l-Musannifîn, İstanbul, 1951, I, 171; Wilhelm Ahlwardt, Verzeichniss der Arabischen Handschriften, Berlin, 1893, V, 66; Brockelmann ve ondan naklen Shiloah, el-Mevsılî'nin 1124/1712'den önce doğduğunu naklederler. (Brockelmann, Supplementband, II, 508) el-Bağdadî’nin verdiği ölüm tarihi doğru ise el-Mevsılı̂’nin doğum tarihinin, Brockelmann'ın belirttiği 1124/1712 yılından çok erken olması gerektiğine veya el-Mevsılî’nin çok genç yaşta öldüğüne hükmetmek gerekir.

3 el-Bağdâdî, I, 171; Müellifin biyografisi hakkındaki bu kısa malumat için ayrıca bkz: Ömer Rıza Kehhâle, Mu'cemu'l-Müellifîn, Beyrut 1957, I, 270; Hayruddin ez-Ziriklî, el-'Alâm, Da- 
Hanefî̀nin ifadesine göre, Davud Çelebi, Mahtûtâtu'l-Mevsıl adlı kitabında el-Müsellem'in bir şiir divanı olduğunu belirtir. Yine Celal Hanefi, Said Deveci'den şifahen aldığı bilgiye göre, el-Mevsılî’nin tasavvufla ilgili bir kitabının olduğunu ve bunun Şit Nebi Camiinin kütüphanesinde bulunduğunu yazar. ${ }^{4}$

Ed-Dürru'n-Nakînin asl, Beyânu'l-Makâmâti'l-Aliyye Mea'l-Furûi ve'l-Evzâni'l-Asliyye'dir. Farsça yazılan bu eserin müellifi Abdülmümin el-Belhî'dir. El-Mevsılî, bu risaleyi Arapçaya tercüme etmiş ve asıl nüshaya önemli eklemeler yaptığı için ismini değiştirmiş ve ed-Dürru'n-Nakî fi İlmi'l-Mûsikâ koymuştur. ${ }^{5}$

Ed-Dürru'n-Nakî, Davud Çelebi'nin, 1927 tarihli Mahtûtâtu'l-Mevsıl adlı eserinde ed-Dürru'n-Nakî fi Fenni'l-Mûsîkâ adıyla zikredilmiş kısaca tanıtılmıştır. Davud Çelebi bu Risalenin özel bir nüshasını tanıtırken, 17 sayfa olduğunu, içinde Abdülmümin'e nispet edilen temel makamların tabiatlerini gösteren bir dairenin bulunduğunu ve nüshanın 1124/1712 yilında Osman b. Salih Bey tarafından istinsah edildiğini belirtir. ${ }^{6}$ Celal Hanefi, edDürru'n-Nakî̀nin bir başka nüshasının Musul Müzesi Müdürü Said Deveci'de bulunduğunu, Deveci'nin de elindeki bu nüshayı 1941 yılında Seyyid Abdülğani en-Nakîp elindeki bir nüshadan istinsah ettiğini belirtir. ${ }^{7}$ Celal Hanefi, Said Deveci nüshasından kendisi için istinsah etmiş, daha sonra en-Nakip nüshası karşılaştırmıştır. En-Nakîp nüshasında çok fazla hatanın bulunduğunu söylemektedir. Elinden geldiği kadar, müellif el-Mevsılî’nin“Yanlışlarımı af kalemiyle düzeltsinler." sözüne uyarak hataları düzeltmeye çalıştığını belirtmiştir. ${ }^{9}$

Ed-Dürru'n-Nakî’nin kaynaklarda belirtilen nüshaları şunlardır:

1. Berlin, 5523 Pm. 105/1, 1-7a 200x150(150x93) mm. 24-25 satır. Kalın, sarımtırak ve parlak kağıt, sağlam, miklepli cilt. 2a: Mukaddime, ${ }^{10}$ 2b: 1. bab, 2b: 2. bab, 5b: 3. bab, 6b: hatime. Nüshada nağmelerin etkileri ile ilgili bir zeyl bulunmaktadır. 1200/1785 yllında istinsah edilmiştir. ${ }^{11}$

ru'l-İlm, Beyrut 1989, I, 147-148; Shiloah, s. 287. Corci Zeydan, Tarihu Âdâbi'l-Lüğati'lArabiyye, Daru'l-Hilal, t.y, b.y, III, 365.

4 Ahmed el-Müsellem el-Mevsılî, ed-Dürrü’n-Nakî fi İlmi'l-Mûsikâ, (neşr. Celal Hanefî), Dâru'lCumhuriyye, Bağdat, 1964, s. 3.

5 el-Mevsilî, s. 4.

6 el-Mevslîi, s. 5-6. Celal Hanefi bu risaleyi göremediğini ifade etmektedir.

7 Bu nüsha Irak Müzesi yazmaları içinde kayıtlıdır. Bkz. dipnot 13.

8 Bkz. bu çalışma, s. 4.

9 el-Mevsılî, s. 6-7. Hanefi, bu nüshayı esas alarak Risaleyi 1964 yılında yayımlamıștır. Tercümede kullandığımız çalışma da Celal Hanefi'nin bu yayınıdır.

10 Shiloah'a göre mukaddime vr. 1a'dadır. bkz. s. 289.

11 Shiloah, s. 289; Ahlwardt, V, 66. 
2. British Museum Add. Nr. 23494, 10 varak, 205x140 (158x84)mm., 21 satır, 2b: Mukaddime, 4a: 1. bab; 4b: 2. bab; 5b: 3. bab; 7b: hatime. ${ }^{12}$

3. Irak Müzesi Yazmaları, nr. 15146/1, 14. sayfa, 15x21 cm. 18 satır. İstinsah tarihi, $1270 / 1853 .{ }^{13}$

\section{Risalenin Tercümesi}

\section{Ed-Dürru'n-Nakî fi IIlmi'l-Mûsika}

Bize İslam dinini lütfeden, insanların efendisi olan Peygamberi ile bize doğru yolu gösteren, ikram ve nimetlerle bizi yaratılmışların çoğundan şerefli kllan, bizi ibadetle sorumlu tutan ve her birimize bir makam veren Allah'a hamt olsun.

Bütün eksik sıfatlardan tenzih ettiğimiz Allah, bize, "Ben sizin Rabb'iniz değil miyim?" hitabını buyurmuş, "Evet, şahit olduk (ki Rabbimizsin)."14 cevabını vermeyi bize ilham etmiştir. Bize, kendisine uymakla istikameti emretmiş ve yüksek dereceler vaat etmiştir. Bütün akl-1 selim sahiplerini azameti ile hayrette bırakmıştır. İnsanoğlunun idraki daha sorunun başında cevaptan aciz kalmaktadır. Nimetler nehrinin arkasını idrak edemez zihinler, hikmetler denizini nasıl idrak etsinler?

Hicaz'a gitmek üzere Irak'tan kervanını yüklemiş ve bol rızık veren Allah'ın emirlerine muhalefet etmeden Beytü'l-Atik'e karşı durmuş olan kimse gibi Allah'a hamt ederim. Ben şehadet ederim ki Allah'tan başka ilah yoktur. O tektir ve ortağı yoktur. Bütün mevsimler ve zamanlar onundur. Şehadetim öyledir ki şekten, şüpheden ve Isfehan insanının bidatlarından uzaktır. Yine şehadet ederim ki Hz. Muhammed onun kulu ve elçisidir. O elçi ki Allah zulüm ve nifak ehline karşı ona yardım etmiştir. Allah onunla Necd ve Hicazlıları şereflendirmiştir. O sebeple Necd ve Hicaz, aşıkların uğrağı olmuştur. Allah'ım! Efendimiz Hz. Muhammed'e onun ehl-i beytine ve ashabına salâtu selam olsun, vezinler denk geldiği, furû usûlden türediği ve nevruz-1 arap, nevruz-1 acemin önüne geçtiği müddetçe.

Bundan sonra aciz bir kul olan Ahmed b. Abdurrahman el-Mevsılî der ki, bazı kardeşler benden, kâmil bir üstad, fazilet ve irfan ehlinin hocası Abdülmümin el-Belhînnin risalesini onlar için tercüme etmemi istediler. Allah, emziren annelerin emzirmeyi unutacağı, hamilelerin hamlini bırakacağı günün dehşetinden onu emin kılsın. O risalesini Farsça yazmış, adını el-Makâ-

12 Shiloah, s. 289; Osmanlı Mûsikîsi Literatürü Tarihi, Ircıca Yay. İsatanbul 2003, s. 102.

13 Osmanlı Mûsikîsi Literatürü Tarihi, s. 102. (Üsame Nasır en-Nakşibendî Mahtûtâtu'l-Mûsîkâ ve'l-Ğtna ve's-Sema fi'l-Mektebeti'l-Mathafi'l-Irakî, s. 16-17'den naklen).

14 A'râf suresi, 7/172. 
mâtü'l-Aliyye Mea'l-Furûi ve'l-Evzâni'l-Asliyye koymuştur. Benden dört tabiatlı (hava, su, toprak, ateş) makamları onlara açıklamamı istediler ki onu duyan ve düşünenler ondan büyük bir lezzet alsın. Farsça ve makam bilgimdeki eksiklik sebebiyle ondaki bazı amaçları görememiş olabilirim.

Baktım ki onlar, bu isteklerinden vazgeçmiyorlar, aramızdaki sözü de uzatmamak için onların isteklerine olumlu cevap verdim. Bunu yaparken Fettâh olan Allah'tan, cömertlik ve hoşgörü denizi olan onun Peygamberi Muhammed (a.s.) den yardım istedim. Farsça herhangi bir müşkül sözcük olduğunda onu Arapça ile açıkladım. Bu eserime ed-Dürru'n-Nakî fi İlmi'lMûsikâa ${ }^{15}$ adını verdim.

Risaleyi, bir mukaddime, üç bölüm ve bir hatime olarak düzenledim.

Mukaddime: Makamların aslını, neden meydana geldiklerini ve bu ilme niçin mûsikî adının verildiğini açıklar.

1. Bölüm: Her bir makamın Peygamberlerden birisine dayandığını ve yedi asıl makam olduğunu açıklar.

2. Bölüm: Makamların daireleri, bunların burçlar ve feleklerle ilişkisi hakkındadır.

3. Bölüm: Makamların tabiatları ve okurken onlara uygun harfler hakkindadir.

Hatime: Meclisler ve dinleyenlerin tabiatlarına göre her meclise karşllık gelen makamlar, bunların okunması, makamlar arası geçiş, hangi makamla başlanıp hangisiyle biteceği hakkındadır.

Bu satırlar üzerinde duran kemal ehli insanlardan ricam şudur: Yanlışlarımı afv kalemiyle düzeltsinler ve onları en güzel sözlerle telafi etsinler. Aynı zamanda eksikliğim yüzünden beni yargılamasınlar. Bu sanattaki kulacım kısadır. Yardımcı olan Allah'tan isteğim, bu eserimi dinleyenlerin kalbinde etkili ve faydalı kılmasıdır. Amin.

\section{Mukaddime}

\section{Makamların Aslının Açıklanması}

Bu ilme mûsikî denmesinin nedeni, rivayet edilen şu hadisedir: Musa (a.s.), İsrailoğulları'na Sina çölünde gelen susuzluk üzerine Allah'a kırk yıl boyunca dua ile meşgul oldu. Cebrail (a.s.) geldi ve dedi ki: "Ey Musa! Allah sana selam söyler ve der ki: Asanla taşa vur ki kudret ve hikmetimi göresin." ${ }^{16}$ Musa (a.s.) asasıyla taşa vurdu. O taştan on iki çeşme fışkırdı.

15 Müellif eserin adını burada bizzat zikretmiştir. Bazı kaynaklarda ise Risalenin adı, ed-Dürru’nNakî fi Fenni'l-Mûsikâ olarak yer almaktadır. Bkz. El-Bağdadî, I, 171; Brockelmann, Supplementband, II, 508; Kehhale, I, 270; Ahlwardt, V, 66.

16 Tevrat, Çıkış 17. 
Bunun üzerine her çeşmeden bir diğerine benzemeyen güzel bir ses çıktı. On iki makam işte bundan alınmıştır. Meselenin aslı budur. Cebrail (a.s.) dedi ki; "Ey Musa! Sula. " Bu iki kelime (Musa ile eskı) kısaltılarak bu sanatın ismi olmuş ve mûsikî denmiştir.

\section{Birinci Bölüm}

Her bir makam bir peygamberin lahnidir ve yedi temel makam vardır.

Fazilet sahibi bazı kişilerden, temel makamların yedi tane olduğu, bu makamlardan her birinin bir peygambere ait olduğu rivayet edilmiştir. Şeyh Safiyyüddîn Nüzhetü'l-Enâm fì Tarîfi Külli Veznin ve Makâm ${ }^{17}$ adlı eserinde rivayetin ilk bölümünün daha doğru ve tercih edilir olduğunu söylemiştir.

Asıl makamların yedi tane olduğunu söyleyen kimse onları şöyle sıralamiştır.

Rast; Adem (a.s.) 1n, "Rabbimiz! Kendimize zulmettik."18 dediği zamanki makamdir.

Uş̧̧ak; Musa (a.s.) in, Firavun'un adamlarından birini öldürdüğünde, Rabbim onlardan bir kişiyi öldürdüm."19 dediği zamanki makamdır.

Irak; Yusuf (a.s.) in, "Ey Rabbim! Zindan bana, bunların beni dâvet ettiği şeyden daha sevimlidir." ${ }^{20}$ dediği zamanki makamdır.

Maveraünnehr; Yunus (a.s.) in, balığın ağzına girdiğinde, “...karanlıklar içinde, "Senden başka hiçbir ilah yoktur. Seni eksikliklerden uzak tutarım. Ben gerçekten (nefsine) zulmedenlerden oldum"21 dediği anki makamdir.

Hüseynî; Davud (a.s.) 1n, "Derken Rabb'inden bağısslama diledi, eğilerek secdeye kapandr ve Allah'a yöneldi." ${ }^{\prime 2}$ ayetinde belirtilen, tevbe secdesinde bağışlanma dilerken kullandığı makamdır.

Hicazi; İbrahim (a.s.) in oğlu İsmail'i kurban edeceği vakit, ona; "Yavrum, ben rüyamda seni boğazladığımı gördüm. Düşün bakalım, ne dersin?"23 sözünü söylediği zamanki makamdır.

17 Ed-Dürru'n-Nakînnin, Safiyyüddîn Abdülmümin el-Urmevî’nin eserlerinden iktibas edildiği fikrine zemin hazırlayan bu tür cümlelerdir. Oysa Safiyyüddin'e nispet edilen böyle bir eser bilinmemektedir. Ayrıca makam terimi Safiyyüddîn'in kitaplarında bulunmamaktadır. Bu terim daha sonra kullanılmaya başlanmıştır.

18 'Araf Suresi, 7/23.

19 Kasas suresi, 28/33

20 Yûsuf suresi 12/33

21 Enbiyâ suresi, 21/87

$22 \mathrm{Sa}^{\prime} \mathrm{d}$ suresi, 38/23-24.

23 Saffât suresi, 37/102. 
Neva; İsmail (a.s.) in babasına cevap verirken, "Babacığım, emrolunduğun şeyi yap. İnşaallah beni sabredenlerden bulacaksın." ${ }^{24}$ dediği anki makamdır.

Bunlar asıl makamlardır. Diğerleri furûdur. Asıl makamlar Acem Meliki Şah Şîreviyye zamanına kadar gelmiştir. Diğer makamlar onun zamanında ortaya çıkmış ve on iki olmuştur. Bunun sebebi, onun yanında, mûsikî ilminde çok maharetli Sadi adındaki bir adamdır. Sadi, yedi asıl makamdan, makamların tabiatlarına göre ve on iki burca uygun olarak on iki makam ortaya çıkarmıştır.

\section{ikinci Bölüm}

Makamların Daireleri, Burç, Felek ve Saatlerle iliş̧kileri

Bil ki on iki makam, dört unsurdan oluşmaktadır. Ateş, su, toprak ve hava.

Rast: Elementi/tabiatı ateştir. Burcu ise Koç’tur. Saati, üçüncü felek Zühre'nin ${ }^{25}$ cuma günüdür. Şubelerinden birisi nîrîzdir. Farsça'da buna mâye ve pençgâh denir. Yine murğak olarak da adlandırılmıştır. Makamların birincisidir.

Uş̧̧ak: Elementi su, burcu İkizlerdir. Saati ikinci felek Utarit'in ${ }^{26}$ çarşamba günüdür. Beyâti onun şubelerindendir. Buna humâyûn, hazîn ve kûçek de denir. Bu, makamların ikincisidir.

Irak: Elementi hava, burcu Akreptir. Saati beşinci felek Merih'in ${ }^{27}$ salı günüdür. Sabâ onun şubelerindendir. Ona dügâh, çargâh ve zâvile de denir. Makamların üçüncüsüdür.

Hüseyin el-Perverdî’nin şöyle dediği nakledilmiştir: "Meleklerin, tatll11$\breve{g} 1$ ve lezzeti sebebiyle çargâh makamıyla tespih ettiklerini, sözüne itimat edilen birinden duydum."

Hicazî: Elementi hava, burcu Balık'tır. Saati altıncı felek Müşteri'nin ${ }^{28}$ perşembe günüdür. Onun şubesi dır. ${ }^{29}$ Buna dügâh, hicazî ve hazîn denir. Yine buna kûçek de denir. Makamların dördüncüsüdür.

\footnotetext{
24 Saffât suresi, 37/102.

25 Venüs

26 Merkür

27 Mars

28 Jüpiter

29 Bunun gibi birkaç şube ismini okuyamadık. Birkaçı da aşağıda gelecektir. Bunların, Risalenin yazıldığı bölgeye mahsus şube isimleri olduğu açıktır. Aslen Kerküklü olan Prof. Dr. Mahir Nakip'e de bu şube adlarını sorduk o da bunları el-Maa, Akberi, el-Me'lifet, el-Mülfek olarak okudu ve ilk ikisinin anlamı olmadığını diğer ikisinin de "ellefe" ve "lefeka" kelimelerinden geldiğini belirtti. Shiloah da bunları, maa, akberî, malafat, mulfak olarak yazmıştır. Biz bu şube isimlerini olduğu gibi yazmayı tercih ettik.
} 
Zengûle: Elementi hava, burcu Yengeç'tir. Saati birinci felek Kamer'in ${ }^{30}$ pazartesi günüdür. Onun şubesi aşîrandır. Aynı zamanda buna müberka' ve hüzzâm da denir. Yine buna bestenigâr da denir. Bu, beşinci makamdır.

Muhalif: Elementi su, burcu Terazi'dir. Beşinci felek Merih'in çarşamba günüdür. Şubesi uzzâl'dır. Aynı zamanda buna nühüft ve sûfiyân ${ }^{31}$ denir. Yine buna ruy-i mevzûn da denir. Altıncı makamdır.

Safiyyüddîn'in Nüzhetü'l-Enâm fĩ Tarîfi Külli Veznin ve Makâm'da şöyle dediği rivayet edilmiştir: "Adem'in ruhunu çamur kalıbına girmek üzere getirdiklerinde o kalıptan korktu. Çünkü ruh ulvi idi. Çamur ise süfli. İkisi aynı cins değildir. Allah bir meleğe bu kalıba girmesi için emretti. Melek o kalıba girdi ve içerde Allah'ı tespih etti. Onun tespihi uzzâl makamındaydı. Bunun üzerine Adem'in ruhu buna aşina oldu ve içine girdi. Ruh tam yerleştikten sonra melek buradan çıktı. Bu ses kesilince ruh çıkmayı düşündü. $\mathrm{O}$ anda Hz. Adem doğrularak oturdu. Ondan sonra ruh kaldı ve bu makamı her duyduğunda ona meyletti. ${ }^{32}$

Buselik: Elementi ateş, burcu Aslan'dır. Saati, dördüncü felek Şems'in ${ }^{33}$ pazar günüdür. Onun nişâbûr diye bir şubesi vardır. Buna selmek, nihavend ve geveşt de denir. Yedinci makamdır.

Şâhnâz: Elementi ateş, burcu Yay'dır. Saati altıncı felek Müşteri'nin pazartesi günüdür. Muhayyer adında bir şubesi vardır. Buna beyne'l bahreyn ve evc de denir. Aynı zamanda buna muhayyer-i evc de denir. Sekizinci makamdir.

Hüseynî: Elementi toprak, burcu Başak'tır. Saati ikinci felek Utarit'in çarşamba günüdür. Onun hisar adında bir şubesi vardır. Buna mâveraünnehr ve gerdâniye de denir ve dokuzuncu makamdır.

Mukabil: Elementi toprak, burcu Oğlak'tır. Saati üçüncü felek Zühre'nin cumasıdır. adında bir şubesi vardır. Buna ve vechü'l-hüseynî de denir. Onuncu makamdır.

Neva: Elementi toprak, burcu Boğa, saati üçüncü felek Zühre'nin cuma günüdür. Bu makamın arîbûn adlı bir şubesi vardır. Buna nevrûz-ı arab ve

30 Ay

31 Celal Hanefi bunun Isfehan'dan geldiğini belirtir. Bkz. s. 26.

$32 \mathrm{Bu}$ efsane farklı biçimde şöyle rivayet edilir: "Yüce Allah Adem'in kalıbını yarattıktan sonra ruha, "Adem'in vücuduna gir." diye emreder. Ruh girmeye korkar. O zaman Allah (c.c.) Cebrail'e; "Cennetten Koşney'i getir ve çal." diye emreder. Bu yüce emir üzerine Cebrail, cennetten alıp getirdiği Koşney'i çalınca mest olan ruh bedene girer." Bu efsaneye göre yaratıllı̧ ile birlikte ilk çalgı çalan Hz. Cebrail'dir. Bu sebeple Cebrail, mûsikîșinasların piri kabul edilir. Yine bu efsaneye göre ilk çalgı Koşney yani Çifte'dir." Bkz. Ethem Ruhi Üngör, "Osmanlı'da Türk Musikisi ve Çalgılar", Osmanl, Yeni Türkiye Yayınları, Ankara 1999, X, 582.

33 Güneş 
segâh da denir. Aynı zamanda buna nevrûz-1 acem denir. On birinci makamdır.

Nevrîz: Elementi su, burcu Kova, saati yedinci felekteki Zühal'in ${ }^{34}$ cumartesi günüdür. Bunun nevrûz-ı rum diye bir şubesi vardır. Aynı zamanda buna ırak-1 acem ve necdî ve zirkeş de denir. On ikinci makamdır.

E ğer denilse ki tek bir makamdan iki şube nasıl çıkartılabilir ve sen nasıl çıkarıyorsun? De ki; Şemsuddîn Ebu'l-Fadl Muhammed Kemâl ve Hüseyin el-Mâhir ve iki kâmil üstad olan İbrahim ve İshak ${ }^{35}$ kendi kitaplarında zikretmişlerdir ki makamın şubelerinden birisi makamın başlangıcı, ikincisi ise "meyahane"sidir. ${ }^{36}$

On iki makamın sayısı budur. Şubeleri ile birlikte hepsi otuz altıdır. ${ }^{37}$ Allah daha iyisini bilir.

Bu ilmi bilenler aşağıdaki şeklin doğruluğunda ittifak etmişlerdir. Bu kişiler, üstad Abdülmümin'in üslubunu benimsemişler ve bilgisinin mükemmelliğinden dolayı onun hakkını teslim etmişlerdir. Allah en doğrusunu bilir.

\begin{tabular}{|c|c|c|c|c|c|c|}
\hline Makam & Element & Burç & Gezegen & Guin & Şube & Harf \\
\hline Rast & Ateş & Koç & Zühre & Cuma & $\begin{array}{l}\text { nîrîz, mâye, } \\
\text { pençgâh, } \\
\text { murğak }\end{array}$ & $\begin{array}{l}\text { elif, he, t1, } \\
\text { mim, fe, } \\
\text { şın, zel }\end{array}$ \\
\hline Uşşak & $\mathrm{Su}$ & İkizler & Utarit & Çarşamba & $\begin{array}{l}\text { beyâti, } \\
\text { humayûn, } \\
\text { segâh-1 rekb, } \\
\text { terkib-i hicâzî }\end{array}$ & $\begin{array}{l}\text { cim, ze, kef, } \\
\text { sin, kaf, } \\
\text { te, z1 }\end{array}$ \\
\hline Irak & Hava & Akrep & Merih & Salı & $\begin{array}{l}\text { saba, çargâh, } \\
\text { dügâh-1 rekb, } \\
\text { zâvile }\end{array}$ & $\begin{array}{l}\text { ha, dal, lam, } \\
\text { ayn, r1, h1, } \\
\text { ğayn }\end{array}$ \\
\hline Hicazî & Hava & Balık & Müşteri & Perşembe & $\begin{array}{l}\text { dügâh-1 hicâzî, } \\
\text { hazîn, kûçek }\end{array}$ & $\begin{array}{l}\text { ha, dal, lam, } \\
\text { ayn, rı, } \\
\text { hı, ğayn }\end{array}$ \\
\hline
\end{tabular}

34 Satürn

35 Son sayfada da bu iki isme yer verilmiş ve bunların İbrahim el-A'cemî ve İshak el-Mevsılî oldukları zikredilmiştir.

36 "Meyanhane" olmalıdır. Bu kavram, bilindiği gibi, aslında peşrevlerin üçüncü hanesinde asıl makam dizisinin dışına çıkılarak değişik ses ve diziler kullanılan bölümün adıdır. Günümüzde, meyan bölümü, bütün eserlerin, ana makamın dışına çıkılarak, genellikle tiz seslerde icra edilen bölümleri için kullanılır.

37 Cetvelde sadece 48 adet şube ismi yer almaktadır. 


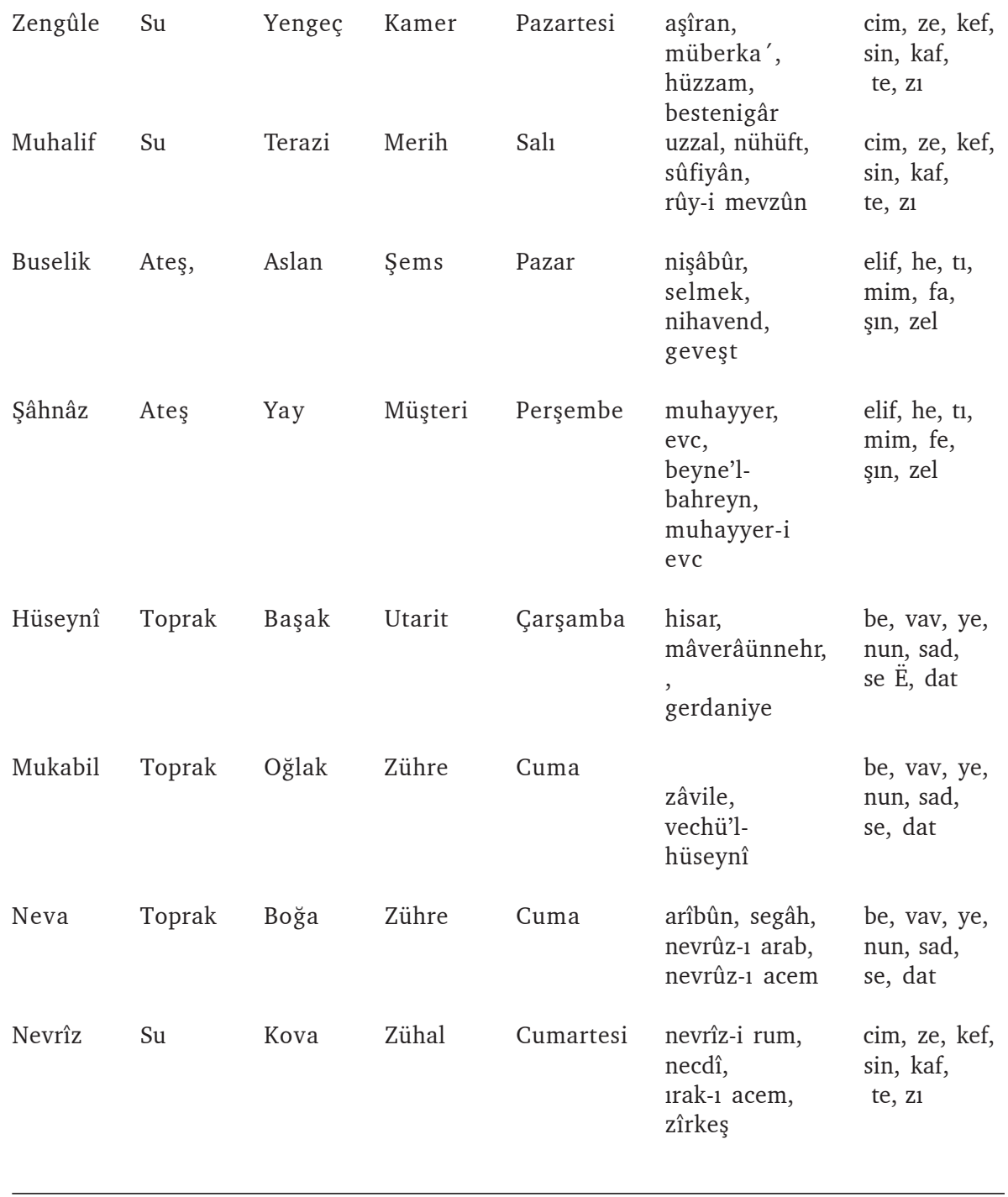

\section{Üçüncü Bölüm}

\section{Makamların Tabiatları ve Onlara Uygun Harfler}

Bil ki bu makamların ve hece harflerinin doğasını bilmek gerekiyor. Bunu fark ettiğin zaman, makamlarla harflerin birbirlerine uyumlu olması gerektiğini anlayacaksın. 
Rast, buselik ve şâhnâz nârîdir. (Elementi ateştir/Ateş karakterlidir.) Hüseynî, mukâbil ve neva toprak karakterli, uşşak, muhâlif ve nevrîz su karakterlidir. Irak, hicaz ve zengûle hava karakterlidir. Herhangi bir makamın alt şubesi de onun asıl karakterine tabî olur.

Bil ki her harfin de karakteri vardır:

Elif, he, t1, mim, fe, şın ve zel, ateş,

Be, vav, ye, sad, te, dat, toprak,

Cim, ze, kef, sin, kaf, te, zı, su,

Ha, dal, lam, ayn, rl, hı, ğayn, hava karakterlidir.

Bu makamlardan bazılarını okumak istediğin zaman, onu, gününde ve saatinde oku ve aynı zamanda okuyuşun, kafiyeye uygun olsun ki senin için bu makamın lezzeti ortaya çısın.

Örneğin rast makamını okumak istediğin zaman bunu, cuma gününün ilk saati oku. Çünkü o Zühre'nin saatidir. Kasidenin kafiyesi de "elif" veya "he" ya da "tı" ve bizim zikrettiğimiz ateş karakterli harfler olmalıdır. Çünkü bu harfler rast makamına uygundur. Böylece her makam, kendisine özgü olan saatler, gece ve gündüzlerle birleşir. Gece ya da gündüzden herhangi bir saati öğrenmek istediğinde aşağıdaki levhaya bak.

Bu levhaya göre pazar gününün saati, perşembe gecesine mahsustur. Pazartesinin saati cumanın gecesi içindir. Salı gününün saati cumartesi gecesi içindir. Çarşamba gününün saati, pazar gecesi içindir. Perşembe gününün saati pazartesi gecesi içindir. Cuma gününün saati salı gecesi içindir. Cumartesi gününün saati çarşamba gecesi içindir. Gece ya da gündüze ait bir saati öğrenmek istediğinde burada çizilmiş levhaya bak.

Bil ki bir makama mahsus olan saat gündüzün başında olur, sonra ortasında olur. Çünkü saatlerin (günlerin) sayısı yedidir. Her gündüz için on iki saatin geçmesi lazım, çizilen levhada olduğu gibi. Bunu idrak et ki doğruyu bulasin.

\begin{tabular}{|c|c|c|c|c|c|c|c|c|}
\hline Günler & Cumartesi & Cuma & Perşembe & Çarşamba & Salı & Pazartes & si Pazar & Günler \\
\hline Geceler & $\begin{array}{c}\text { Çarşamba } \\
\text { gecesi }\end{array}$ & $\begin{array}{l}\text { Salı } \\
\text { gecesi }\end{array}$ & $\begin{array}{c}\text { Pazartesi } \\
\text { gecesi }\end{array}$ & $\begin{array}{l}\text { Pazar } \\
\text { gecesi }\end{array}$ & $\begin{array}{c}\text { Cumartesi } \\
\text { gecesi }\end{array}$ & $\begin{array}{l}\text { Cuma } \\
\text { gecesi }\end{array}$ & $\begin{array}{c}\text { Perşembe } \\
\text { gecesi }\end{array}$ & Geceler \\
\hline Güneşin doğuşu & Zühal & Zühre & Müşteri & Utarit & Merih & Kamer & Şems & 1 \\
\hline Güneşin yükselişi & i Müşteri & Utarit & Merih & Kamer & Şems & Zühal & Zühre & 2 \\
\hline Kuşluk & Merih & Kamer & Şems & Zühal & Zühre & Müşteri & Utarit & 3 \\
\hline
\end{tabular}




\begin{tabular}{|c|c|c|c|c|c|c|c|c|}
\hline $\begin{array}{l}\text { Zevalden önceki } \\
\text { kuşluk }\end{array}$ & Şems & Zühal & Zühre & Müşteri & Utarit & Merih & Ay & 4 \\
\hline Zeval vakti & Zühre & Müşteri & Utarit & Merih & Kamer & Şems & Zühal & 5 \\
\hline Zevalden sonra & Utarit & Merih & Kamer & Şems & Zühal & Zühre & Müşteri & 6 \\
\hline $\begin{array}{l}\text { Öğle ve ikindi } \\
\text { arası }\end{array}$ & Kamer & Şems & Zühal & Zühre & Müşteri & Utarit & Merih & 7 \\
\hline İkindiden önce & Zühal & Zühre & Müşteri & Utarit & Merih & Kamer & Şems & 8 \\
\hline İkindi & Müşteri & Utarit & Merih & Kamer & Şems & Zühal & Zühre & 9 \\
\hline İkindiden sonra & Merih & Kamer & Şems & Zühal & Zühre & Müşteri & Utarit & 10 \\
\hline $\begin{array}{l}\text { Gün batımından } \\
\text { önce }\end{array}$ & Şems & Zühal & Zühre & Müşteri & Utarit & Merih & Kamer & 11 \\
\hline $\begin{array}{l}\text { Gün batımından } \\
\text { sonra }\end{array}$ & Zühre & Müşteri & Utarit & Merih & Kamer & Şems & Zühal & 12 \\
\hline
\end{tabular}

\section{Hâtime}

Dinleyicilerin Tabiatlarına Göre Her Meclise Uygun Olan Makamlar, Makamların Okunması ve Makamdan Makama Geçiş

Bil ki insanların karakterleri farklı farklıdır. Zarifi vardır, kabası vardır. Her makamın bir yeri ve sözü ve her yerin bir adamı ve durumu vardır.

E ğer şeyhlerin ve sufilerin meclisinde isen, mukâbil, nevrûz-1 arab, zengûle ve arîbûn makamında okumalısın. Çünkü onların kalpleri riyâzât ve ibadetlerle hassaslaşmıştır. Tabiatları, nefis mücadelelerinin büyüklüğü sebebiyle selim ve latiftir. En küçük şey onları etkiler. Onlar ateş karakterli makamları dinlediklerinde aşka gelir adeta yanarlar. Toprak ve hava karakterli makamları dinlediklerinde ise kalpleri parçalanır.

Alimler meclisinde isen, uşşak, ırak ve hicazî makamında okumalısın. Çünkü onlar ilimlerinin hararetinin zirvesindedirler. Bu makamlar ise su ve hava karakterlidir.

Türklerin meclisinde isen rast, zengûle, buselik ve ırak makamında okumalısın. Çünkü tabiatları katı ve soğuktur. Kalplerine tesir edecek hararete ihtiyaç duyarlar. Rast, buselik ise ateş karakterlidir.

Avâmın meclisinde isen, , aşîran, hazîn, muhayyer, şâhnâz makamlarında okumalısın. Çünkü onların tabiatları katı ve kuvvetlidir. Şâhnâz, muhayyer ateş, , ve hazîn hava karakterlidir. Çünkü havanın karakteri soğuktur ve onda yanıklık ve hüzün vardır. 
Ĕger dersen ki her makamın bir saati ve bu saatin bir günü olduğuna göre o zaman her makam ancak ait olduğu günde okunacaktır. Buna cevabım şudur: Eğer makam saatine uygun olursa başka bir gün de okunabilir. Örneğin, neva'nın saati, cuma günü Zühre'dir. Fakat Pazartesi Zühre'nin altıncı saati okunabilir. Salı günü Zühre'nin üçüncü saati okunabilir. Cetvele bakarsan saatleri anlarsin.

Bil ki eğer bu makamlardan birini okumak istersen gündüz, gece saatine ve aşağıdaki altı vezinden uygun olanına dikkat etmen gerekir. Usûl ve fürû' olsun makamların hangisiyle başlanıp hangisiyle bitirmenin uygun olacağını bilmen gerekir. Bu örnek üzere okursan dinleyenlerin kalbi açılır ve hayvanlar bile onunla coşarlar.

Altı vezin, şâhnâz, buselik, hisar, ırak, rast, zengûledir. Bu makamların vezin olarak adlandırılmasının sebebi bunların bütün makamlarla ilişkili olmasıdır.

Makamların asıllarına gelince onlar dört tanedir. İlki rast, ikincisi ırak, üçüncüsü zengûle, dördüncüsü mukabildir.

Uş̧̧ak, neva, buselik, şâhnâz, pençgâh, nîrîz, rastın furûudur.

Necdî, saba, çargâh, hüseynî, hisar, maveraünnehr, evc ve nevrîz, ırakın furûudur.

Hüzzam, aşîrân, sûfiyân, beyâtî ve arîbûn, zengûlenin furûudur.

, hazîn, hicâzî, segâh, uzzal, muhalif ve segâh-1 rekb, mukâbilin furûudur.

Bunları öğrendikten sonra bil ki rastı okumaya başladıysan ondan sonra neva, uşşak ve beyatiye geçmeli, hisarla bitirmelisin.

Hüseyni ile başladıysan necdî, muhayyer, sabaya geçmeli, çargâhla bitirmelisin.

Eğer buselik ile başladıysan ondan şâhnâza, evc ve hisara geçmeli maveraünnehr ile bitirmelisin.

Irakla başladıysan ondan nevrîz, necdî, nevrîz-i ruma geçmeli ve aşîran ile bitirmelisin.

Uzzal ile başladıysan, muhalif, sûfiyân, hicazi, , hazîn, mukâbile geçmeli ile bitirmelisin.

Bunlar Abdülmümin el-Belhî, Şemsuddîn Ebu'l-Fadl ve Mevlana Hüseyin el-Perverdî’nin görüşleridir. Abbasiler döneminde seslerinin güzelliği sebebiyle Davud Peygambere nispet edilerek Davudî olarak meşhur olmuş İbrahim el-A'cemî, İshak el-Mevsılî ise şöyle demişlerdir: "Ĕ̆ger bir makamla başladıysan o makamın şubesine geçmeli, sonra başladığın makamla bitirmelisin. Çünkü bu, bir makamdan diğerine geçmekten daha hoş bir icradır." Büyük üstad Yusuf Câmî, İbrahim en-Nihavendî ve Ali er-Rivâyâtî 
ve Mevlana Hüseyin Çakirî ve diğerleri de İbrahim el-A 'cemî, İshak el-Mevsllînin görüşünü benimsemişlerdir.

14 Rebiussani 1270/1853 Perşembe günü tamamlandı.

Said Deveci bu risaleyi, Musul eşrafından Seyyid Abdülğani Efendi'nin elindeki nüshadan 1361 Zilkadenin Çarşambasında (9 Kanunuevvel 1941) kendisi için istinsah etmiştir. Allah'a hamt, Efendimiz Muhammed'e salat-u selam olsun.

\section{Sonuç}

Abbas el-Azzavî, Ed-Dürru'n-Nakînnin Safiyyüddîn'in eserlerinden iktibas edildiğini söylemektedir. Azzavî bu konuda iki görüş ortaya atmaktadır. Bu Risalenin Safiyyüddin'in $\hat{I} k \hat{a}^{\prime}$ adlı Farsça eserinden, el-Mevsilî tarafından Arapça'ya nakledildiğini belirtmektedir. Yine o Şerefiyye'den iktibas edildiğinin ihtimal dahilinde olduğunu ifade etmektedir. ${ }^{38}$

Bu risalenin aslı olan Beyânu'l-Makâmâti'l-Aliyye Mea'l-Furûi ve'l-Evzâni'lAsliyye'nin yazarı Abdülmümin el-Belhî'dir. Risaleyi Farsça yazmıştır. ElMevsılî bu risaleyi Arapçaya tercüme etmiş ve asıl nüshaya önemli eklemeler yaptığı için ismini değiştirmiş ve ed-Dürru'n-Nakî fi İlmi'l-Mûsikâ koymuştur. ${ }^{39}$ İşte Azzavî Abdülmümin el-Belhî̀yi, Safiyyüddîn Abdülmümin el-Urmevî ile karıştırmıştır. Îkâ 've Şerefiyye'den iktibas edildiği şeklindeki bilginin yanlışlığ 1 ise adı geçen eserler incelediği zaman ortaya çıkmaktadır. Görüldüğü gibi ed-Dürrü’n-Nakî'de îkâ' konusuna hiç yer verilmez. ${ }^{40}$ Aynı şekilde Şerefiyye'de ele alınan hiçbir konu bu eserde yer almaz. Mukayese yapabilmek için beş makaleden oluşan Şerefiyye'nin içeriğine göz atalim:

Birinci Makâle: Sesin oluşumu, duyulması, dağılımı, tizlik ve pestlik sebepleri, sesin, nefesli ve telli sazlarda oluşumu ve nitelikleri.

İkinci Makâle: Sayıların birbirlerine oranları, bu oranların isimleri, uyumlu (mülâyim) ve uyumsuz (mütenâfir) aralıklar, aralıkların uyumlu oluş sırasına göre tasnifi.

38 el-Azzâvî, el-Mûsikâ'l-Irâkiyye fi'l-Ahdi'l-Moğol ve't-Türkmân, Bağdat, 1951, s. 33.

39 el-Mevsilî, s. 4.

40 Îkâ 'adlı eserin Farsça yazıldı̆̆ı ve Amasyalı Ahmed oğlu Şükrullah tarafından Türkçe'ye tercüme edildiği yönünde bilgiler vardır. Bkz. el-Azzâvî, el-Mûsîkâ'l-Irâkiyye, s. 33, Safiyyüddîn Abdülmümin el-Urmevî, er-Risâletü'ş-Şerefiyye fi'n-Nisebi't-Te'lifiyye, (Thk. Haşim Muhammed er-Receb) Dâru'r-Reşîd, Bağdat, 1982, s. 13; Âdil el-Bekrî, Safiyyüddîn el-Urmevî, Müceddidü'lMûsika'l-Abbâsiyyeti, Bağdat, 1978, s. 87. 
Üçüncü Makâle: İkinci makâlede tertip edilen aralıkların birbirleri ile toplanması ve çıkarılması, orta (vustâ) aralıklardan cinslerin (dörtlü ve beşliler) tertibi, isimleri ve bunların uyumlu ve uyumsuzları.

Dördüncü Makâle: Büyük aralık tabakaları içerisinde cinslerin tertibi, tertip edilen cinslerin oranları ve sayıları, dörtlü ve beşlilerle bir ve iki oktavlık dizilerin oluşturulması, ud sazının akordu, ud üzerindeki perdeler ve oranları, dörtlü ve beşlilerle makamların tasnifi, isimleri ve perdelerinin cetvellerle gösterilmesi, farklı akortlarla icra ve intikal (notalar arasında geçiş) konusu.

Beşinci Makâle: Îkâ' ve devirlerinin oranları ve beste yapım bilgileri. ${ }^{41}$

Safiyyüddîn birçok müzik yazmasında olduğu gibi ed-Dürru'n-Nakî'de de yer alan astrolojik tariflere, mûsikî-tıp, mûsikî-gök cisimleri ilişkisine, sayıların kutsallı̆̆ı gibi konulara er-Risâletü'ş-Şerefiyye'de yer vermemiştir. Görüldüğü gibi iki eser arasında bir benzerlik bulunmamaktadır.

Risalenin metni tümüyle incelendiği zaman, bu eserde yer alan konuların, Safiyyüddîn'in Abdülmümin el-Urmevî'nin ve er-Risâletü'ş-Şerefiyye'sinde ele alınan konularla benzer olmadığı görülecektir.

Risale, astrolojik konulara yer veren mûsikî kaynaklarına güzel bir örnektir. Ancak verilen bilgilerle, bu tarzda yazılan diğer örnekler arasında önemli farklılıklar bulunmaktadır.

Makamların asıl ve füru olarak tasnifinde farklılıklar var. Risalede önce temel makamların yedi olduğu ifade edilmekte bunlar bir peygambere dayandırılmakta, sonra temel makamların on ikiye çıktığı belirtilmektedir. Yine temel makamların aslında 4 tane olduğu kaydedilmektedir. Arkasından, daha önce asıl makamlardan sayılan bazı isimler bu dört makamın fürûu içinde zikredilmektedir.

Risalede özellikle kulağa hoş gelen melodinin insan ve hayvanlar üzerindeki etkileri, icra sırasında makamlar arası geçişin, insan kulağına hoş gelmesi için gelişigüzel yapılmaması konularında önemli bilgiler verilmektedir.

41 Fazlı Arslan, Safiyyüddîn-i Urmevî ve Şerefiyye Risâlesi, Atatürk Kültür, Dil ve Tarih Yüksek Kurumu, Atatürk Kültür Merkezi, Ankara 2007, s. 31-32. 